\title{
Enhanced Protective Effect of Ultrafine Particles of Red-Ginseng against Phenanthrene-induced Cell Damage
}

\author{
Yoo-Na Seo and Mi-Young Lee* \\ Department of Medical Biotechnology, SoonChunHyang University, Asan, Chungnam 336-600, Korea \\ (Received November 26, 2009; Revised December 11, 2009; Accepted December 14, 2009)
}

\begin{abstract}
Phenanthrene, one of the polycyclic aromatic hydrocarbons, has been known to be toxic to the environment. In this investigation, the protective effect of red ginseng on phenanthrene-induced oxidative DNA damage was evaluated using Comet assay in A549 cells. Red ginseng's cytoprotective effect on phenanthrene-induced hemolysis was also investigated. This study's findings show that oxidative DNA damage and hemolysis were significantly prevented by red ginseng treatment. Notably, it was found that pulverizing red ginseng into ultra-fine particles even enhanced its protective effects against DNA damage and hemolysis. The results suggest that particle size reduction seems to effectively enhance red ginseng's pharmacological efficacies.
\end{abstract}

Key words : red ginseng, particle size reduction, cytoprotection, phenanthrene

\section{INTRODUCTION}

The revolution in nanotechnology gives advantages in diverse areas, and the resulting nanoparticles play important roles in a wide variety of industrial applications. Nanoparticles are already being used in medicines, cosmetics, food additives, disinfectants, fuel additives etc. Nanotechnology has also provided a theoretical and technical evidence for showing the increase in solubility and bioavailability of the bioactive components in drugs and foods.

The physico-chemical properties of nanoparticles are quite different from those of the same compounds on a larger scale. ${ }^{1)}$ When the materials were reprocessed at the nano scale, the properties of the nano-sized materials were significantly different from their larger equivalents. Chemical reactivity, color, strength, conductivity, and magnetic properties of the nano-sized materials may all vary in extraordinary ways. Insoluble materials might easily dissolve at the nano scale, and the nano-sized particles could penetrate into the cellular membranes that their bulk particles normally cannot. ${ }^{2)}$

Ginseng, the root of Panax ginseng C.A. Meyer, has been used as a representative tonic in Korea. Although ginseng exhibits multiple pharmacological efficacies, ${ }^{3)}$ it's

\footnotetext{
* Corresponding author. E-mail: miyoung@sch.ac.kr
} Phone: +82-41-530-1355, Fax: +82-41-530-1355 precise mechanisms on the actions are still elusive. The main molecular components responsible for the action of ginseng are the ginsenoside, which are also known as ginseng saponins. ${ }^{4)}$ More than 30 different forms of ginseng saponins have been isolated and identified. ${ }^{5-7)}$ Ginsenosides are a class of steroid glycosides and triterpene saponins hence ginsenoside has a four-ring, steroid-like structure with sugar moieties attached. ${ }^{8)}$ Ginsenosides are often classified as three groups based on their structural differences: the $\mathrm{Rb} 1$ group, $\mathrm{Rg} 1$ group and oleanane group. The $\mathrm{Rb} 1$ group was characterized by the presence of protopanaxadiol presence, named $\mathrm{Rb} 1, \mathrm{Rb} 2, \mathrm{Rc}$ and $\operatorname{Rg} 3$. $\operatorname{Rg} 1$ group was classified by the presence of propanaxatriol, named $\mathrm{Rg} 1$, Re, Rf, and $\mathrm{Rg} 2 .{ }^{9)}$

Phenanthrene is one of the polycyclic aromatic hydrocarbon (PAH) composed of three fused benzene rings, ${ }^{10)}$ and they can exist in over 100 different combinations. PAHs are found naturally in the environment but they can be formed from the incomplete burning of the products like coal, oil, gas, and garbage. ${ }^{11)}$ Phenanthrene, like most PAHs, is used to make dyes, plastics and pesticides, explosives and drugs. ${ }^{12)}$ A number of PAHs have caused tumors in laboratory animals by exposure through food, skin, and contaminated air. Other effects including damage to skin, body fluids and the immune system could also be seen.

The comet assay (single-cell gel electrophoresis assay) has been widely used to detect primary DNA damage in 
human and animal cells exposed to various environmental toxicants or occupational exposure. ${ }^{13,14)}$ It is a well-established genotoxicity test for estimating oxidative DNA damage at the individual cell level, both in blood and in cells. ${ }^{15)}$

In this study, the suppressive effects of red ginseng on the oxidative DNA damage and the hemolysis were evaluated. Notably, the enhancement of the protective effect of red ginseng was shown by reducing particle size of red ginseng.

\section{MATERIALS AND METHODS}

\section{Cell culture and sample treatment}

The A549 cell line (American type culture collection, Rockvile, MD), human pulmonary epithelial cell line derived from a lung carcinoma, was used in this experiment. Mycoplasma-free cells were cultured in Dulbecco's modified Eagle's medium (HyClone. Logan. UT, USA) supplemented with $10 \%$ fetal bovine serum (HyClone. Logan. UT, USA) and maintained at $37^{\circ} \mathrm{C}$ under an atmosphere of $5 \% \mathrm{CO}_{2}$, and harvested with $0.05 \%$ Trypsin/ EDTA. Both of the coarse particles and ultrafine particles of red ginseng (Panax ginseng C.A. Meyer) were supplied from NT\&BT Co. Ltd (Chungnam, Korea). Coarse particles and ultrafine particles of red ginseng were each dissolved in PBS at a concentration of 3,5, and $8 \mu \mathrm{g} / \mathrm{mL}$. A549 cells were pre-incubated with various concentrations of red ginseng for $1 \mathrm{~h}$ And then phenanthrene dissolved in DMSO was added to the cells to investigate the effect of red ginseng to protect against phenanthreneinduced cell damage. PBS without an oxidative stimulus was used as a negative control.

\section{Determination of DNA damage by comet assay}

The alkaline comet assay using cultured cells was performed according to Singh et $a l^{16)}$ with slight modifications. A549 cells $\left(5.5 \times 10^{5}\right.$ each) were seeded into 12 well plate (Becton Dickinson, USA). The cells were cultivated overnight and then pretreated with ginseng coarse particles or ultrafine particles for $1 \mathrm{~h}$ at $37^{\circ} \mathrm{C}$. Cells were washed with PBS and then treated with phenanthrene dissolved in the media for $1 \mathrm{~h}$. After washing with PBS, the cells were trypsinized with $250 \mu \mathrm{L}$ of $0.05 \%$ Trypsin/ EDTA. The cells were washed with PBS and then mixed with $75 \mu \mathrm{L}$ of $0.7 \%$ low melting point agarose after adding $500 \mu \mathrm{L}$ media. And then, the cells were added to slides precoated with $1.0 \%$ normal melting point agarose. After the agarose was solidified, the slides were covered with $100 \mu \mathrm{L}$ of $0.7 \%$ low melting point agarose and immersed in lysis solution (2.5 M NaCl, $100 \mathrm{mM}$ EDTA, $10 \mathrm{mM}$ Tris, $1 \%$ sodium lauryl sarcosine, $1 \%$ Triton $\mathrm{X}$ 100 and $10 \%$ DMSO) for $1 \mathrm{~h}$ at $4^{\circ} \mathrm{C}$. The slides were placed into an electrophoresis tank containing $300 \mathrm{mM}$ $\mathrm{NaOH}$ and $10 \mathrm{mM} \mathrm{Na} 2$ EDTA (pH 13.0) for $20 \mathrm{~min}$ to allow the DNA to unwind. Electrophoresis was performed at $25 \mathrm{~V} / 300 \mathrm{~mA}$ for $20 \mathrm{~min}$ at $4^{\circ} \mathrm{C}$. The slides were washed three times with neutralizing buffer $(0.4 \mathrm{M}$ Tris$\mathrm{HCl}, \mathrm{pH} \mathrm{7.5)} \mathrm{for} 5 \mathrm{~min}$ at $4^{\circ} \mathrm{C}$ and then treated with ethanol for a further $5 \mathrm{~min}$ before staining.

\section{Image analysis}

The slides were stained with ethidium bromide $(20 \mu \mathrm{g} /$ $\mathrm{mL}$ ) and coverslipped. Measurements were made by image analysis using Komet 5.5 software (Kinetic Imaging, Liverpool, UK) and fluorescence microscopy (Leica, Wetzlar, Germany). To quantify DNA damage in the comet assay, the olive tail moment was calculated as: (Tail.mean Head.mean)×Tail\% DNA/100. ${ }^{17)} \mathrm{A}$ total of 150 randomly captured comets were examined from each slide.

\section{MTT assay}

The MTT assay was used to determine the cell viability. A549 cells were cultured in a 96-well plate (Corning Inc., Corning, NY) at a density of $2 \times 10^{4}$ cells per well. The cells were then treated with varying concentrations of coarse particles and ultrafine particles of red ginseng for 1 $\mathrm{h}$. And then the cells were treated with $30 \mathrm{M}$ phenanthrene, after which the plates were incubated at $37^{\circ} \mathrm{C}$ in the dark for $2 \mathrm{~h}$ following MTT treatment. After formation of formazan, $100 \mu \mathrm{L}$ of DMSO was added and the absorbance was measured at $570 \mathrm{~nm}$ using ELISA reader.

\section{Hemolysis assay}

$100 \mu \mathrm{L}$ of erythrocyte suspension $\left(5 \times 10^{7}\right.$ cells $\left./ \mathrm{mL}\right)$ was incubated with various concentrations of coarse particles and ultrafine particles of red ginseng for $1 \mathrm{~h}$ at $4^{\circ} \mathrm{C}$. And then $0.9 \mathrm{mM}$ phenanthrene was added to the mixtures for $3 \mathrm{~h}$ at the ice. The degree of hemolysis was determined by measuring the absorbance of the supernatant at $540 \mathrm{~nm}$, as previously reported. ${ }^{18)}$ The absorbance of the control group was used as the blank.

\section{Statistical analysis}

The data for comet assay and hemolysis were the means of three determinations and were analyzed using the SPSS package for Windows version 13 (SPSS Inc., Chicago, IL). The mean values for DNA damage and erythrocyte 
damage for each treatment were compared using one-way analysis of variance (ANOVA) followed by Duncan's multiple range test. $P<0.05$ was considered significant.

\section{RESULTS AND DISCUSSION}

\section{Phenanthrene-induced oxidative DNA damage}

Nanotechnology is being introduced in food and medicine, because the solubility and bioavailability of bioactive components could be enhanced by particle size reduction of the bioactive components in food and medicine. The small size and high surface-volume ratio might endow the particles with increased active groups. Thus the small size and high reactive surface are totally different from their bulk particles. Korean red ginseng was pulverized into ultrafine particles to investigate whether the tiny particles reduced at almost nano grade might have increased cytoprotective effect against oxidative DNA damage and hemolysis. The protective effects of ultrafine particles were compared with those of coarse particles in this investigation.

Fig. 1 shows the scanning electron microscopy (SEM) images of ultrafine particles and coarse particles of red ginseng. The mean size of the ultrafine particles was in the $300-400 \mathrm{~nm}$ range, while that of the coarse particles was in the $100-150 \mu \mathrm{m}$ range as determined by density analysis of the particles (data not shown).

The comet assay has been used in toxicity testing and biomonitoring, and it has proven to be a sensitive system for genotoxicity screening. Comet assay are also useful for detecting oxidative DNA damage induced by the generation of free radicals. In Fig. 2, A549 cells were treated with various concentrations of phenanthrene. The DNA damage, determined by the olive tail moment in a comet assay, increased in a dose-dependent manner. The olive tail moment at $30 \mathrm{M}$ phenanthrene was about $47.94 \pm 5.33$,

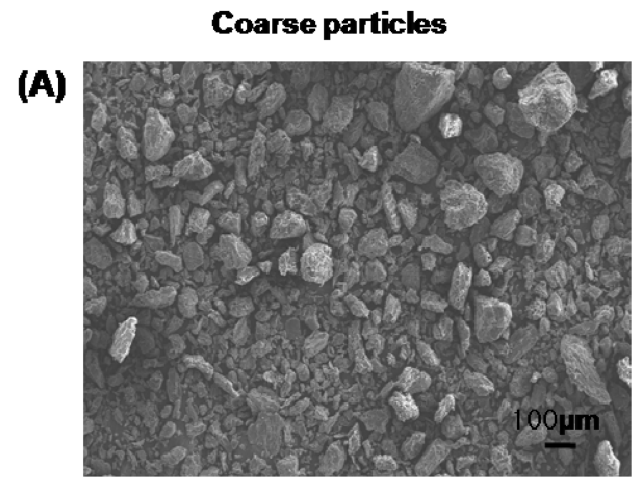

compared with $6.24 \pm 0.16$ in the PBS-treated control, indicating an approximately 8-fold increase in DNA damage at $30 \mu \mathrm{M}$ phenanthrene. Various oxidants such as hydrogen peroxide, paraquat and melamine have been reported to cause DNA strand breakage by generating hydroxyl radicals close to the DNA molecule. ${ }^{19,20)}$ Paraquat (10 $\mu \mathrm{M})$ showed an approximately 3-fold increase in DNA damage in comparison with the control, ${ }^{20)}$ while $10 \mu \mathrm{M}$ phenanthrene induced approximately 4-fold more DNA damage than the control. These results indicate that phenanthrene-induced oxidative DNA damage is greater than paraquat-induced DNA damage.

\section{Suppressive effect of red ginseng on phenanthrene- induced oxidative DNA damage}

The addition of red ginseng inhibited the oxidative DNA damage caused by various concentrations of phenanthrene, as demonstrated by the reduction of the olive tail moment in a comet assay (Fig. 3). Coarse particles as well as ultrafine particles of red ginseng could protect the A549 cells from DNA damage induced by $30 \mu \mathrm{M}$ phenanthrene. Notably, ultrafine particles could protect the cell much better than coarse particles as evaluated with olive tail moment. The olive tail moment of $3 \mu \mathrm{g} / \mathrm{mL}$ ultrafine particle-pretreated cells was approximately $13.97 \pm 0.19$, while that of the coarse particle-pretreated cells was approximately $21.96 \pm 0.42$, indicating stronger protective effect of ultrafine particles than that of coarse particles. Same enhanced protective effects were also seen at 5 and $8 \mu \mathrm{g} /$ $\mathrm{mL}$ of ultrafine particles. The olive tail moment at $5 \mu \mathrm{g} /$ $\mathrm{mL}$ ultrafine particles was approximately $12.39 \pm 4.11$, while that of the coarse particles was approximately 16.28 \pm 4.24 . The olive tail moment at $8 \mu \mathrm{g} / \mathrm{mL}$ ultrafine particles was approximately $11.57 \pm 0.12$, while that of the coarse particles was approximately $14.35 \pm 0.64$.

Much more antioxidant activity, ginsenosides, minerals,

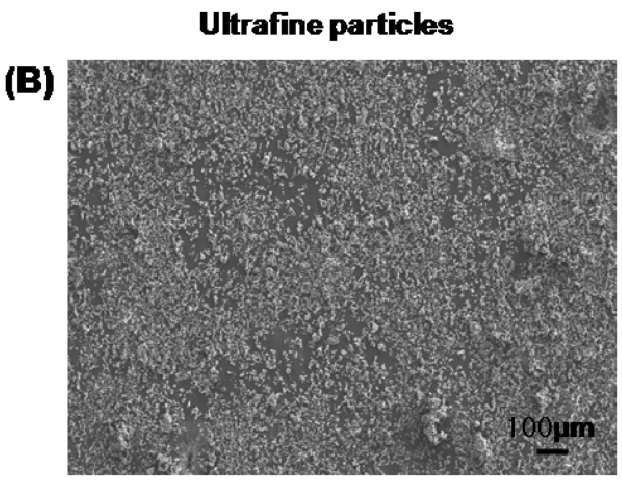

Fig. 1. SEM images of coarse particles (A) and ultrafine particles (B) of red ginseng. 


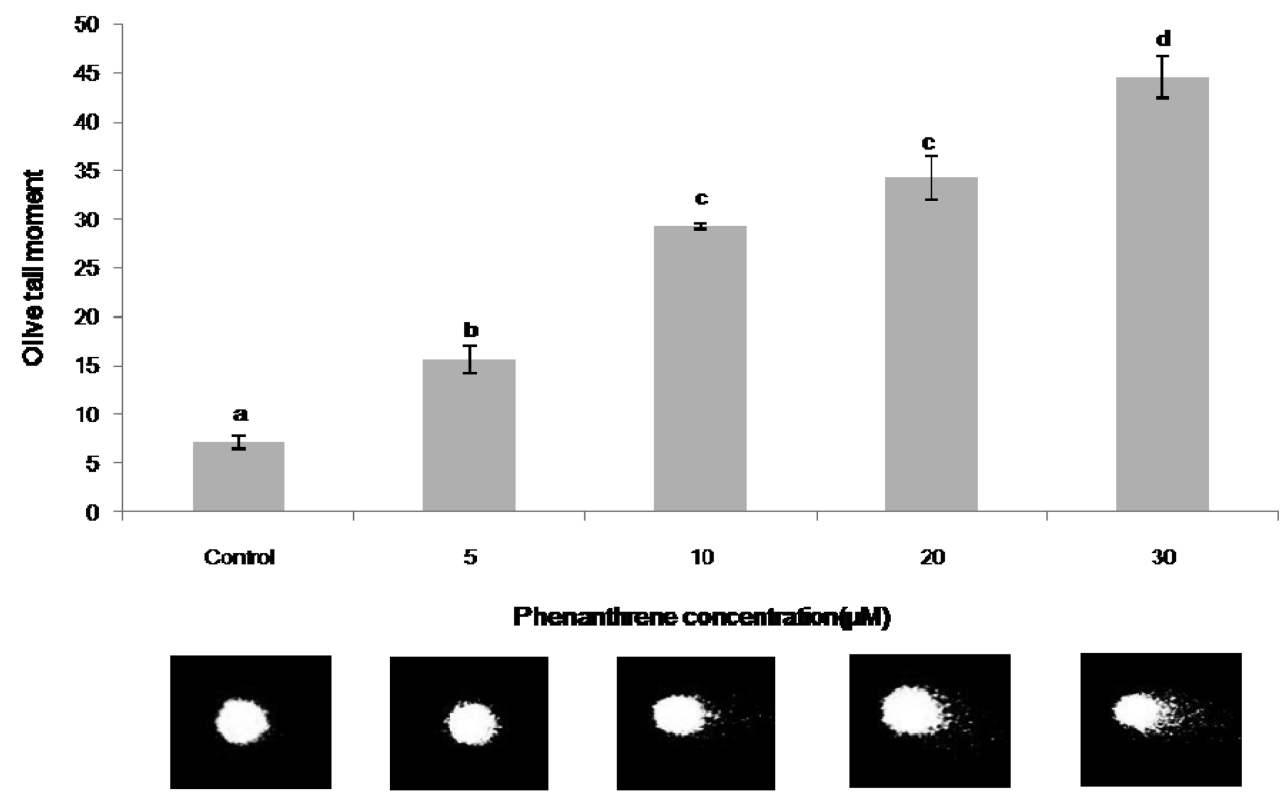

Fig. 2. Phenanthrene-induced oxidative DNA damage of A549 cells evaluated with comet assay. Values not sharing the same letter are significantly different from one another $(p<0.05)$ according to Duncan's multiple range test.

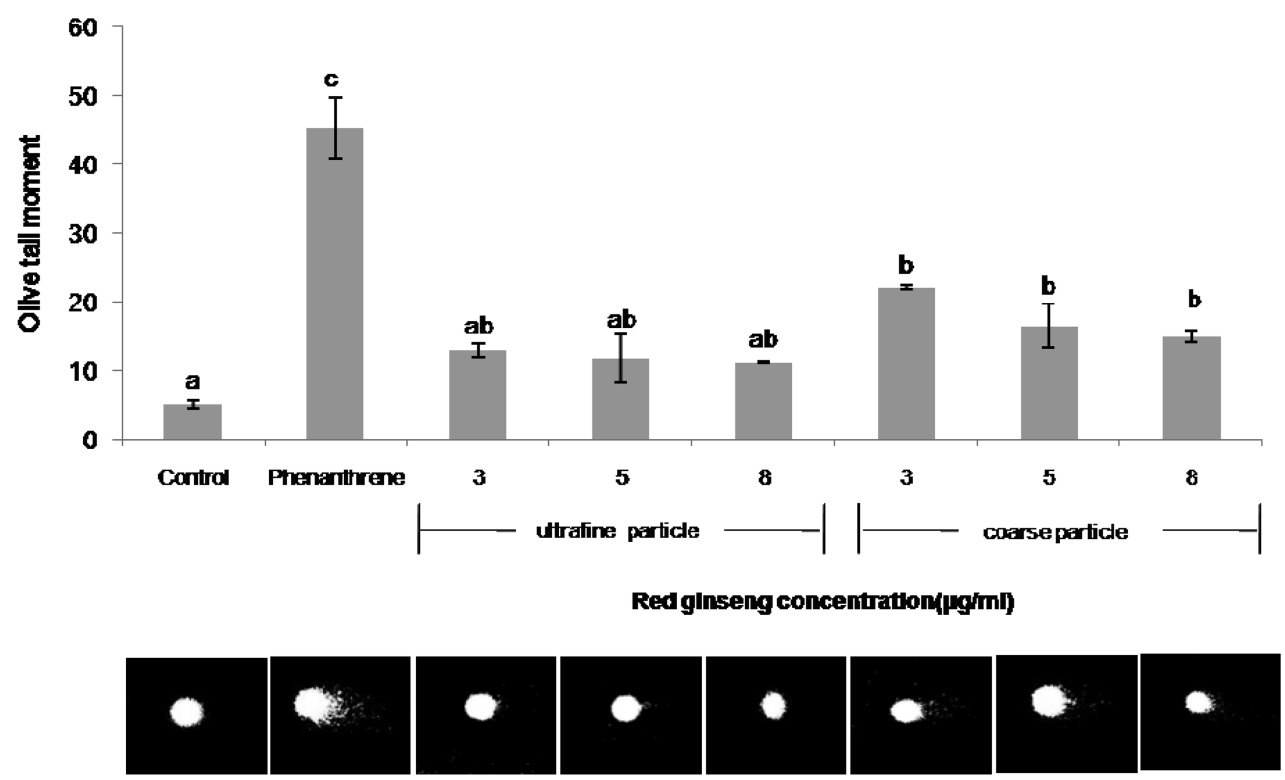

Fig. 3. Protective effect of ultrafine particles and coarse particles of red ginseng on phenanthrene -induced DNA damage in A549 cells. Values not sharing the same letter are significantly different from one another $(p<0.05)$ according to Duncan's multiple range test.

carbohydrates, lipids and proteins were reported to be detected in the ultrafine particles than in regular particles in our previous report. ${ }^{21)}$ Especially, the sum of all the saponins detected in ultrafine particles was about twice more than in regular particles. ${ }^{21)}$ Therefore, more antioxidative components including ginsenosides, polyphenols and flavonoids in ultrafine particle seem to suppress the oxidative DNA damage more strongly than in coarse particles.

Suppressive effect of red ginseng on phenanthreneinduced hemolysis

Fig. 4 shows the information on erythrocytes morphology and stability under phenanthrene treatment. The 


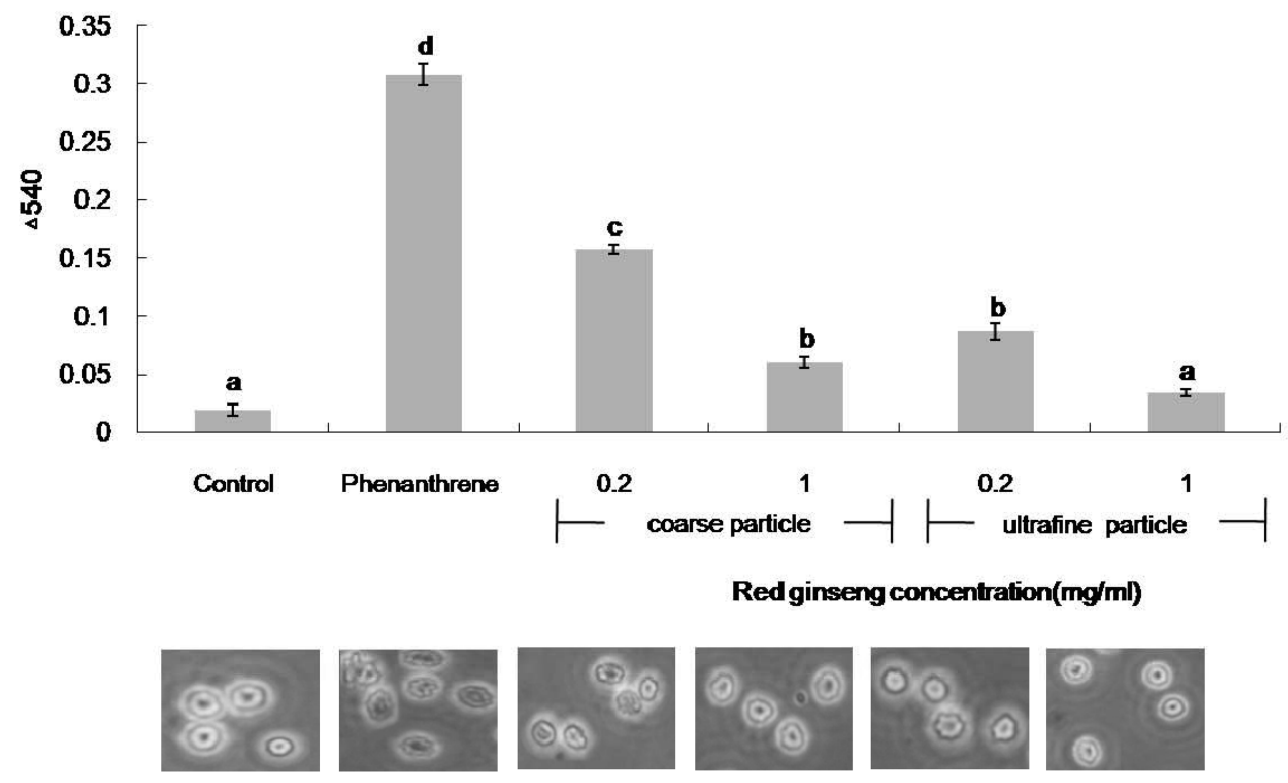

Fig. 4. Protective effect of ultrafine particles and coarse particles of red ginseng on phenanthrene-induced hemolysis. Values not sharing the same letter are significantly different from one another $(p<0.05)$ according to Duncan's multiple range test.

erythrocyte was not damaged at $30 \mu \mathrm{M}$ phenanthrene that caused significant oxidative DNA damage by using comet assay, while the erythrocytes treated with $0.9 \mathrm{mM}$ phenanthrene exhibited abnormal shapes in morphology. However, the numbers of abnormal shapes of erythrocytes were reduced when the erythrocytes were pretreated with red ginseng. Another result of the damage by phenanthrene was hemolysis, which happened when the content escaped from the inner to the outer membrane of erythrocyte $^{22)}$ upon treating phenanthrene. However, phenanthrene-induced hemolysis was reduced sharply under ultrafine particle treatment while slowly under coarse particles of red ginseng. The result indicates the enhanced cytoprotective effect of ultrafine particles of red ginseng than that of coarse particles. The reason for this difference may be related with the tiny size and high surface activity of ultrafine particles.

There is increasing evidence showing that a variety of diseases are associated with increased oxidative stress. ${ }^{23)}$ Oxidative stress has been implicated in the pathogenesis of diverse diseases. The beneficial effects of red ginseng could be attributed to various ginsenosides, while the mechanism of actions of ginsenoside remains to be elucidated. In this examination, we examined the enhanced protective efficacies of ultrafine particles of red ginseng against DNA damage and hemolysis than those of the equivalent larger ones. These results suggest that nanotechnology including particle size reduction could be applied to the development of enhanced medicinal foods primarily because the small size, high surface-volume ratio and enhanced absorption could endow them with increased reactive groups.

\section{ACKNOWLEDGMENTS}

This subject was supported by the Korean Ministry of Environment as part of "The Eco-technopia 21 project".

\section{REFERENCES}

1. Stone V, Nowack B, Baun A, van den Brink N, von der Kammer F, Dusinska M, Handy R, Hankin S, Hassellöv M, Joner E, Fernandes TF. Nanomaterials for environmental studies: classification, reference material issues, and strategies for physico-chemical characterisation. Sci Total Environ In press. (2009)

2. Lanone S, Boczkowski J. Biomedical applications and potential health risks of nanomaterials: molecular mechanisms. Curr Mol Med. 6: 651-663 (2006)

3. Hong B, Ji YH, Hong JH, Nam KY, Ahn TY. A double-blind crossover study evaluating the efficacy of Korean red ginseng in patients with erectile dysfunction: a preliminary report. J Urol. 168: 2070-2073 (2002)

4. Kim JH, Nah SY. Effect of ginsenoside total saponins on experimental irritable bowel syndrome in rats. J Ginseng Res. 29: 94-99 (2005)

5. Lee JH, Chio SH, Kwon OS, Shin TJ, Lee JH, Lee BH, Yoon 
IS, Pyo MK, Rhim H, Lim YH, Shim YH, Ahn JY, Kim HC, Chitwood DJ, Lee SM, Nah SY. Effects of ginsenosides, active ingredients of Panax ginseng, on development, growth, and life span of Caenorhabditis elegans. Biol Pharm Bull. 30: 2126-2134 (2007)

6. Li X, Wang G, Sun J, Hao H, Xiong Y, Yan B, Zheng Y, Sheng L.Pharmacokinetic and absolute bioavailability study of total panax notoginsenoside, a typical multiple constituent traditional Chinese medicine (TCM) in rats. Biol Pharm Bull. 30: 847-851 (2007)

7. Ko SR, Suzuki Y, Suzuki K, Chio KJ, Cho BG. Marked production of ginsenosides $\mathrm{Rd}, \mathrm{F} 2, \mathrm{Rg} 3$, and compound $\mathrm{K}$ by enzymatic method. Chem Pharm Bull (Tokyo). 55: 15221527 (2007)

8. Lee JH, Choi SH, Nah SY. Study on life span extension efficacy by Korean red ginseng. J Ginseng Res. 31: 210-216 (2007)

9. Ma Y, Eun JS, Oh KW. Therapeutic effects of ginseng on psychotic disorders. J Ginseng Res. 31: 117-126 (2007)

10. Pesch B, Kappler M, Straif K, Marczynski B, Preuss R, Rossbach B, Rihs HP, Weiss T, Rabstein S, Pierl C, Scherenberg M, Adams A, Käfferlein HU, Angerer J, Wilhelm M, Seidel A, Brüning T. Dose-response modeling of occupational exposure to polycyclic aromatic hydrocarbons with biomarkers of exposure and effect. Cancer Epidemiol Biomarkers Prev. 16: 1863-1873 (2007)

11. Liu Y, Li H, Lin JM. Magnetic solid-phase extraction based on octadecyl functionalization of monodisperse magnetic ferrite microspheres for the determination of polycyclic aromatic hydrocarbons in aqueous samples coupled with gas chromatography-mass spectrometry. Talanta 3: 1037-42 (2009)

12. Gianfreda L, Antonietta Rao M, Piotrowska A, Palumbo G, Colombo C. Soil enzyme activities as affected by anthropogenic alterations: intensive agricultural practices and organic pollution. Sci Total Environ. 341: 265-279 (2004)

13. Lee EM, Lee SY, Lee WS, Kang JS, Han ES, Go SY, Sheen
YY, Kim SH, Park SN. Genetic toxicity test of o-nitrotoluene by ames, micronucleus, comet assays and microarray analysis. Mol Cell Toxicol. 3: 107-112 (2007)

14. Garaj-Vrhovac V, Gajski G, Trosi I, Pavici I. Evaluation of basal DNA damage and oxidative stress in Wistar rat leukocytes after exposure to microwave radiation. Toxicology 259: 107-112 (2009)

15. Hartwig A. Role of DNA repair in particle- and fiber-induced lung injury. Inhal Toxicol. 14: 91-100 (2002)

16. Singh NP, McCoy MT, Tice RR, Schneider EL. A simple technique for quantitation of low levels of DNA damage in individual cells. Exp Cell Res. 175: 184-191 (1988)

17. Sul DG, Oh SN, Lee EI. The expression of DNA polymeraseand DNA damage in jurkat cells exposed to hydrogen peroxide under hyperbaric pressure. Mol Cell Toxicol. 4: 66-71 (2008)

18. Katsu T, Kuroko M, Morikawa T, Sancika K, Fujita Y, Yamamura $\mathrm{H}$, Uda M. Mechanism of membrane damage induced by the amphipatic peptides gramicidin S and melittin. Biochim Biophys Acta 983: 135-141 (1989)

19. Park SK, Lee MY. Suppressive effect of various antioxidants on melamine-induced oxidative DNA damage in human lymphocytes. Mol Cell Toxicol. 5: 243-249 (2009)

20. Park EJ, Ryoo KK, Lee YB, Lee JK, Lee MY. Protective effect of electrolyzed reduced water on the paraquat-induced oxidative damage of human lymphocyte DNA.J Korean Soc Appl Biol Chem. 48: 155-160 (2005)

21. Park SK, Kim YK, Yoon HS, Lee MY. Application of nanotechnology to Korean black-red ginseng: solubility enhancement by particle size reduction. Mol Cell Toxicol. 4: 52-60 (2008)

22. Hebbel RP, Leung A, Mohandas N. Oxidation-induced changes in microrheologic properties of the red blood cell membrane. Blood 76: 1015-1020 (1990)

23. Diplock AT. Antioxidant nutrients and disease prevention: an overview. Am J Clin Nutr. 53: 189S-193S (1991) 